\title{
Monitoring of Virulence Genes, Drug-Resistance in Campylobacter coli Isolated from Golden Retrievers
}

\author{
MAREK SELWET ${ }^{1 *}$, MARIOLA GALBAS ${ }^{2}$, RYSZARD SŁOMSKI², TOMASZ CŁAPA ${ }^{1}$ \\ and FILIP PORZUCEK ${ }^{2}$ \\ ${ }^{1}$ Department of General and Environmental Microbiology, University of Life Sciences Poznań, Poland \\ ${ }^{2}$ Department of Biochemistry and Biotechnology, University of Life Sciences, Poznań, Poland
}

Submitted 6 July 2015, revised and accepted 9 October 2015

\begin{abstract}
The investigation was performed on 75 of Golden Retriever puppies. Faecal samples were collected on the 42 day of the puppies life (control). Probiotic preparation was administered on 43 day of the puppies life and 10 days after the application of the probiotic, faecal samples were collected again (on 53 day of puppies life). All isolates of Campylobacter coli isolated prior to the administration of the probiotic were found to contain the $\mathrm{cadF}$ gene responsible for adhesion, as well as, the flaA gene influencing motility of the examined bacteria. Significant differences $(\mathrm{P}<0.05)$ were recorded only in the case of enrofloxacin.
\end{abstract}

Ke y wo rds: Campylobacter coli, dogs microflora, drug-resistance, virulence genes

Campylobacter coli is the most seldom reported Campylobacter spp. in the majority of dog populations sampled (Acke et al., 2009). However, some studies have found Campylobacter jejuni to be the most commonly isolated species in dogs, particularly outside of Europe (Tsai et al., 2007). Other species of Campylobacter such as C. coli and Campylobacter lari have also been isolated from dogs on occasion, but these species are usually of very low prevalence (Rossi et al., 2008). At the moment, it is believed that the following genes are responsible for the pathogenicity of Campylobacter spp.: flaA gene conditioning motility, cadF - affecting adhesion, $c d t \mathrm{~B}$ - responsible for toxin production and iam - determining invasiveness (Krutkiewicz, 2008). The European Food Safety Administration (EFSA) and the European Centre for Disease Control (ECDC) published the second joint report concerning antibiotic resistance of pathogenic bacteria infecting people, animals and food articles. Campylobacteriosis is the most frequently recorded animal-born infection in humans. High resistance of Campylobacter spp. strains to some antimicrobiological substances, including ciprofloxacin constitutes a growing problem in EU countries (EFSA, 2014). The aim of this study was to show varied shares of virulence genetic markers among strains isolated from dogs with diarrhea. The aim of the second stage of experiments was to presents impact of two commonly applied methods on changes in drug - resistance of the obtained isolates.

The investigation was performed on 75 of Golden Retriever puppies. Campylobacter sp. isolates were obtained from the rectum using swab kits with transport substrate (Euro Tubo Collection Swab Rubi, Spain). Faecal samples were collected on the 42 days of puppies life (control), (moment of weaning). Probiotic preparation was administered on 43 days of puppies life and 10 days after the application of the probiotic, faecal samples were collected again (on 53 day of puppies life to examine possible changes in C. coli drug-resistance).

The applied preparation BioProtect $200 \mathrm{mg}$ (VetExpert) contained $5 \times 10^{6} \mathrm{CFU}$ of Lactobacillus acidophilus, Enterococcus faecium, Bifidobacterium longum, Lactobacillus rhamnosus, and manno-oligosaccharides, fructooligosaccharides. The probiotic was administered 2 capsules daily for 10 days.

Campylobacter isolates were cultured at $42 \pm 1^{\circ} \mathrm{C}$ in Campy Selective Agar Base Preston (Neogen) for $48 \mathrm{~h}$ in an atmosphere composed of $6 \%$ oxygen, $10 \%$ carbon dioxide and $84 \%$ nitrogen. Campylobacter spp. identification was performed using PCR for the detection of C. jejuni and C.coli. The following positive strains: C. jejuni ATCC 33560 and C. coli ATCC 33559 were

\footnotetext{
* Corresponding author: M. Selwet, Department of General and Environmental Microbiology, University of Life Sciences Poznań, Poland; e-mail: marek.selwet@gmail.com
} 
also included. All strains were preserved in 20\% glycerol at $-70^{\circ} \mathrm{C}$. Extraction of DNA (Andrzejewska et al., 2011) was performed using CHELEX-100 chelating resin (Bio-Rad). Bacterial colonies were suspended in $100 \mu \mathrm{l}$ Tris buffer and $45 \mu \mathrm{l} 20 \%$ CHELEX and boiled for $10 \mathrm{~min}$. Samples were then immediately placed on ice for $1 \mathrm{~min}$ and centrifuged at $13.000 \mathrm{~g}$ for $10 \mathrm{~min}$ at room temperature. The supernatant $(2 \mu \mathrm{l})$ was used in PCR. The purity and concentration of DNA were estimated using spectrophotometry at 260 and $280 \mathrm{~nm}$. The presence of the $c a d \mathrm{~F}, f l a \mathrm{~A}, c d t \mathrm{~B}$ and $i a m$ genes was determined with the primers given by Nachamkin et al. (1993), Konkel et al. (1999), Carvalho et al. (2001) and Bang et al. (2001). All PCR amplifications (Andrzejewska et al., 2011) were performed in a mixture $(25 \mu \mathrm{l})$ containing: $2.5 \mu$ of the PCR buffer $(10 \times$ concentrated), $2.5 \mu \mathrm{l}$ of $\mathrm{MgCl}_{2}(25 \mathrm{mM}), 0.5 \mu \mathrm{l}$ of dNTPs $(10 \mathrm{mM}), 1 \mu \mathrm{l}$ of each primer $(100 \mu \mathrm{M}), 0.5 \mu \mathrm{l}(1 \mathrm{U})$ of the Taq thermostable DNA polymerase (Promega Corporation), $2 \mu \mathrm{l}$ of the bacterial template DNA and $15 \mu$ l nuclease free water. The PCR products were analyzed by electrophoresis in $1.5 \%$ agarose gel. The size of the PCR amplicons was compared to the $100 \mathrm{bp}$ DNA marker (Promega Corporation).

In order to assess the resistance of the isolates, the disc method was employed using the following antibiotics (Oxoid): ciprofloxacin $(5 \mu \mathrm{g})$, enrofloxacin $(5 \mu \mathrm{g})$, erythromycin $(15 \mu \mathrm{g})$ and tetracycline $(30 \mu \mathrm{g})$ Culturing was conducted on nutrient broth (NB Merck) which, after 18 hours of incubation at the temperature of $37^{\circ} \mathrm{C}$, was diluted at 1:10.000 in sterile physiological liquid. The suspension $(500 \mu \mathrm{l}$ each) was screened onto plates with Mueller-Hinton (Oxoid) substrate and discs with antibiotics were placed on the agar surface. Following 18 -hour incubation at $37^{\circ} \mathrm{C}$, inhibition zone diameters were determined. The control of antibiotic activity was carried out with the assistance of the C. coli ATCC 33559 reference strain.

E test strips were used in accordance with the manufacturer's instructions. They were removed from $-20^{\circ} \mathrm{C}$ storage and brought to room temperature prior to use. Mueller - Hinton agar plates supplemented with defibrinated 5\% sheep blood (Oxoid) were inoculated by swabbing evenly in three directions with a 0.5 McFarland standard of the test organism. Four E test strips were applied to the surface of the plate in an equidistance radial manner, with the lowest concentration toward the centre. Plates were incubated under the same condition as for disc diffusion. MICs were read directly from the test strip at the point where the zone of inhibition intersected the MIC scale on the strip. National Committee for Clinical Laboratory Standards were used for interpretation of the results (Murat et al., 2005).

Results of investigations regarding numbers of microorganisms were subjected to statistical analysis using the $g l m$ procedure of the SAS (2012) program and the significance of differences was verified by Duncan's test.

All isolates of C. coli isolated prior to the administration of the probiotic were found to contain the cadF gene responsible for adhesion, as well as, the flaA gene influencing motility of the examined bacteria. The $c t d \mathrm{~B}$ gene, involved in preconditioning the development of CDT toxin, was identified in $48 \%$ of the isolates, whereas gene iam, affecting invasiveness - in $49.3 \%$. The examination of the isolates obtained after the administration of the probiotic failed to reveal any significant influence of the probiotic on the frequency of occurrence of the above - mentioned genes (Table I). Table II presents the results of the comparison of two methods of determination of resistance of isolates (obtained prior to probiotic administration) to selected antibiotics. Two tests (disc diffusion test and E Test strips) which were used to determine quantities of isolates sensitive (S) and resistant $(\mathrm{R})$ were compared to the applied antibiotic. In case of ciprofloxacin, erythromycin, and tetracycline, the results of the two tests did not differ significantly in terms of statistic. Significant differences $(\mathrm{P}<0.05)$ were recorded only in the case of enrofloxacin. C. coli isolates obtained prior to the administration of the probiotic revealed the highest resistance in relation to ciprofloxacin and enrofloxacin. Numerical data towards susceptible and resistant isolates turned out to be similar to the results obtained in the control group.

As mentioned above, Campylobacter spp. are among the most frequently reported bacterial cause of human gastroenteritis worldwide (CDC, 2008). The invasive ability of a Campylobacter is strongly affected by its motility, provided by the flagellum. This has been demonstrated by studies that inactivated the flaA gene (encodes for the filament of the flagella) or generated mutant bacteria, and found that this affected mobility and thus invasiveness (Konkel et al., 1999). In the carried studies, this gene was identified in $100 \%$ of the

Table I

Numbers and percentages of virulence genes in C. coli (PCR)

\begin{tabular}{|l|c|c|c|c|}
\hline \multirow{2}{*}{ Isolate group } & \multicolumn{3}{|c|}{ Number of positive isolates } \\
\cline { 2 - 5 } & cadF & flaA & cdtB & iam \\
\hline Dogs (control) C. coli $(\mathrm{n}=75)$ & $75(100 \%)$ & $75(100 \%)$ & $36(48 \%)$ & $37(49.3 \%)$ \\
\hline Dogs (diet with probiotic) C. coli $(\mathrm{n}=75)$ & $75(100 \%)$ & $75(100 \%)$ & $38(50.7 \%)$ & $37(49.3 \%)$ \\
\hline
\end{tabular}


Table II

Results of susceptibility testing of 75 isolates $C$. coli by disc diffusion and $\mathrm{E}$ test methods for four antibiotics (control)

\begin{tabular}{|l|c|c|}
\hline Antimicrobial agents & E Test & Disc diffusion \\
\hline Ciprofloxacin $(5 \mu \mathrm{g})$ & $38 \mathrm{~S}\left({ }^{\star} \mathrm{MIC} \leq 1 \mu \mathrm{g} \mathrm{m}{ }^{-1}\right)$ & $38 \mathrm{~S}(\geq 21 \mathrm{~mm})$ \\
\cline { 2 - 3 } & $37 \mathrm{R}\left(\mathrm{MIC} \geq 4 \mu \mathrm{g} \mathrm{ml}^{-1}\right)$ & $37 \mathrm{R}(\leq 15 \mathrm{~mm})$ \\
\hline Enrofloxacin $(5 \mu \mathrm{g})$ & $43 \mathrm{~S}\left(\mathrm{MIC} \leq 1 \mu \mathrm{g} \mathrm{ml}^{-1}\right) \mathrm{a}$ & $60 \mathrm{~S}(\geq 23 \mathrm{~mm}) \mathrm{b}$ \\
\cline { 2 - 3 } & $32 \mathrm{R}\left(\mathrm{MIC} \leq 2 \mu \mathrm{g} \mathrm{ml}^{-1}\right) \mathrm{a}$ & $15 \mathrm{R}(\leq 16 \mathrm{~mm}) \mathrm{b}$ \\
\hline Erythromycin $(15 \mu \mathrm{g})$ & $72 \mathrm{~S}\left(\mathrm{MIC} \leq 0.5 \mu \mathrm{g} \mathrm{ml}^{-1}\right)$ & $73 \mathrm{~S}(\geq 23 \mathrm{~mm})$ \\
\cline { 2 - 3 } & $3 \mathrm{R}\left(\mathrm{MIC} \geq 8 \mu \mathrm{gl}^{-1}\right)$ & $2 \mathrm{R}(\leq 13 \mathrm{~mm})$ \\
\hline Tetracycline $(30 \mu \mathrm{g})$ & $74 \mathrm{~S}\left(\mathrm{MIC} \geq 4 \mu \mathrm{g} \mathrm{ml}^{-1}\right)$ & $74 \mathrm{~S}(\geq 19 \mathrm{~mm})$ \\
\cline { 2 - 3 } & $1 \mathrm{R}\left(\mathrm{MIC} \geq 16 \mu \mathrm{g} \mathrm{ml}{ }^{-1}\right)$ & $1 \mathrm{R}(\leq 14 \mathrm{~mm})$ \\
\hline
\end{tabular}

* Minimum inhibitory concentration (MIC) specified by the National Committee for Clinical Laboratory Standards (2002); S - susceptible, R - resistant; a, b - means in rows designated with the same letters do not differ significantly at the level of $\mathrm{P}<0.05$

Table III

Results of susceptibility testing of 75 isolates $C$. coli by disc diffusion and $\mathrm{E}$ test methods for four antibiotics (diet with probiotic)

\begin{tabular}{|l|c|c|}
\hline \multicolumn{1}{|c|}{ Antimicrobial agents } & E Test & Disc diffusion \\
\hline Ciprofloxacin $(5 \mu \mathrm{g})$ & $37 \mathrm{~S}\left({ }^{*} \mathrm{MIC} \leq 1 \mu \mathrm{g} \mathrm{ml}^{-1}\right)$ & $37 \mathrm{~S}(\geq 21 \mathrm{~mm})$ \\
\cline { 2 - 3 } & $38 \mathrm{R}\left(\mathrm{MIC} \geq 4 \mu \mathrm{g} \mathrm{m}^{-1}\right)$ & $38 \mathrm{R}(\leq 15 \mathrm{~mm})$ \\
\hline \multirow{2}{*}{ Enrofloxacin $(5 \mu \mathrm{g})$} & $45 \mathrm{~S}\left(\mathrm{MIC} \leq 1 \mu \mathrm{g} \mathrm{ml}^{-1}\right) \mathrm{a}$ & $61 \mathrm{~S}(\geq 23 \mathrm{~mm}) \mathrm{b}$ \\
\cline { 2 - 3 } & $30 \mathrm{R}\left(\mathrm{MIC} \leq 2 \mu \mathrm{g} \mathrm{m}{ }^{-1}\right) \mathrm{a}$ & $14 \mathrm{R}(\leq 16 \mathrm{~mm}) \mathrm{b}$ \\
\hline Erythromycin $(15 \mu \mathrm{g})$ & $74 \mathrm{~S}\left(\mathrm{MIC} \leq 0.5 \mu \mathrm{g} \mathrm{ml}^{-1}\right)$ & $73 \mathrm{~S}(\geq 23 \mathrm{~mm})$ \\
\cline { 2 - 3 } & $1 \mathrm{R}\left(\mathrm{MIC} \geq 8 \mu \mathrm{g} \mathrm{m}^{-1}\right)$ & $2 \mathrm{R}(\leq 13 \mathrm{~mm})$ \\
\hline Tetracycline $(30 \mu \mathrm{g})$ & $73 \mathrm{~S}\left(\mathrm{MIC} \geq 4 \mu \mathrm{g} \mathrm{ml}^{-1}\right)$ & $73 \mathrm{~S}(\geq 19 \mathrm{~mm})$ \\
\cline { 2 - 3 } & $2 \mathrm{R}\left(\mathrm{MIC} \geq 16 \mu \mathrm{g} \mathrm{ml}^{-1}\right)$ & $2 \mathrm{R}(\leq 14 \mathrm{~mm})$ \\
\hline
\end{tabular}

isolates from both experimental groups. According to the investigations by Andrzejewska et al. (2011) and Selwet and Galbas (2012a; 2012b) on C. coli occurrence in people, dogs, cats, and piglets, the presence of the flaA gene in all the examined isolates was also recorded (Selwet et al., 2015). The next factor affecting virulence is gene $c a d F$, which is responsible for production of adhesines. In the experiments, the cadF gene was found also in $100 \%$ of isolates from both study groups. Some researchers attribute a high importance of the cadF gene leading to campylobacteriosis in human (Selwet and Galbas, 2012a). Cytokines such as interleukin-8 (IL-8) are secreted by host cells in response to bacterial invasion, acting as early warning signs to the host immune system, and Campylobacter spp. flagellum and cytolethal distending toxin (CDT) are both thought to stimulate the secretion of IL- 8 from host cells (Zheng et al., 2008). In the carried studies, the $c d t \mathrm{~B}$ gene was identified in $48-50.7 \%$ of the isolates. The iam gene responsible for invasiveness, was found to occur at a similar level (49.3\%). Carvahlo et al. (2001) reported that the iam gene occured less frequently in C. coli. Referring to the EFSA report (2014), antibio- tics which are most commonly used in the treatment of people, animals are fluorochinolons (e.g. ciprofloxacin) ability to mutation in the gyrase - coding gene, which leads to changes in this protein and reduces affinity to fluorochinolons. According to Krutkiewicz (2008) approximately $55.9 \%$ to $59 \%$ of Campylobacter sp. strains show resistance to ciprofloxacin. In the experiments, resistance to mentioned antibiotic was observed in both experimental groups at the level of 49.3-50.7\%. Tambur et al. (2010) compared the E test strips and disc diffusion methods and observed a distinct increase of the determined antibiotics to which C. coli and C. jejuni were resistant. The two tests, which were used to investigate drug - resistance failed to show any differences in the amount of antibiotics to which C. coli were sensitive. Campylobacter sp. are able of producing many toxins, which can damage red blood cells. Many of these toxins/hemolysins are considered virulence factors because of their ability to increase the availability of iron to the pathogen throughout the process of infection via lyses of erythrocytes and subsequent release of heme from hemoglobin (Istivan et al., 2008; Selwet and Galbas, 2012a). Summing up, the prevalence of C. coli 
in dogs are low, suggesting that this population of dogs is unlikely to be a common source of $C$. coli infection for humans. The examined animals were symptomless carriers of these rods. However, great abundance of cadF and flaA genes as well as smaller of $c d t \mathrm{~B}$ and iam genes in strains isolated from those puppies can pose a threat associated with increase of their pathogenicity. In our studies Campylobacter strains exhibited high resistance to ciprofloxacin, enrofloxacin and low resistance to erythromycin and tetracycline. Resistance to ciproflaxin was also determined in strains derived from animals (in particular, from chickens, pigs and cattle) as well as from food articles (EFSA, 2015).

\section{Literature}

Acke E., K. McGill, O. Golden, B.R. Jones, S. Fanning and P. Whyte. 2009. Prevalence of thermophilic Campylobacter species in household cats and dogs in Ireland. Vet. Rec. 164: 44-47. Andrzejewska M., J.J. Klawe, B. Szczepańska and D. Śpica. 2011. Occurence of virulence genes among Campylobacter jejuni and Campylobacter coli isolates from domestic animals and children. Polish J. Vet. Sci. 2: 207-211.

Bang D.D., F. Scheutz, P. Ahrens, K. Pedersen, J. Blom and M. Madsen. 2001. Prevalence of cytolethal distending toxin (cdt) genes and CDT production in Campylobacter spp. isolated from Danish broilers. J. Med. Microbiol. 50: 1087-1094.

Carvalho A.C., G.M. Ruiz-Palacios, P. Ramos-Cervantes, L.E. Cervantes, X. Jiang and L.K. Pickering. 2001. Molecular characterization of invasive and noninvasive Campylobacter jejuni and Campylobacter coli isolates. J. Clin. Microbiol. 39: 1353-1359.

Centers for Disease Control and Prevention (CDC). 2008. Update: recall of dry dog and cat food products associated with human Salmonella Schwarzengrund infections-United States, 2008. MMWR Morb Mortal Wkly Rep. 57: 1200-1202.

European Food Safety Authority and European Centre for Disease Prevention and Control (EFSA). 2015. The European Union Summary Report on antimicrobial resistance in zoonotic and indicator bacteria from humans, animals and food in 2013. EFSA Journal 13: 6 . European Food Safety Authority and European Centre for Disease Prevention and Control (EFSA). 2014. The European Union Summary Report on antimicrobial resistance in zoonotic and indicator bacteria from humans, animals and food in 2012. EFSA Journal 10: 233.
Istivan T.S., S.C. Smith, B.N. Fry and P.J. Coloe. 2008. Characterization of Campylobacter concisus hemolysins. FEMS Immunol. Med. Microbiol. 54: 224-235.

Konkel M., S.A. Gray, B.J. Kim, S.G. Gravis and J. Yoon. 1999. Identification of enteropathogens Campylobacter jejuni and Campylobacter coli based on the cadF virulence gene and its product. J. Clin. Microbiol. 37: 510-517.

Krutkiewicz A. 2008. Campylobacteriosis in humans and animals (in Polish). Życie Wet. 83: 285-288.

Murat Y., I. Ersin, A. Burcu and U. Nilgun. 2005. Comparison of disc diffusion and $\mathrm{E}$ test ${ }^{\circledR}$ for in vitro antimicrobial susceptibility testing of Campylobacter jejuni and Campylobacter coli isolated from polutry. Revue Méd. Vét. 156: 510-513.

Nachamkin I., K. Bohachic and C.M. Patton. 1993. Flagellin gene typing of Campylobacter jejuni by restriction fragment length polymorphism analysis. J. Clin. Microbiol. 31: 1531-1536.

National Committee for Clinical Laboratory Standarts. 2002. Performance Standarts for Antimicrobial Disk and Dilution Susceptibility Tests for Bacteria Isolated from Animals: Approved StandardSecond Edition. M31-A2. NCCLS, Wayne, PA, USA.

Rossi M., M.L. Hanninen, J. Revez, M. Hannula and R.G. Zanoni. 2008. Occurrence and species level diagnostics of Campylobacter spp., enteric Helicobacter spp. and 312 Anaerobiospirillum spp. in healthy and diarrheic dogs and cats. Vet. Microbiol. 129: 304-314.

SAS. 2012. User's quide. Statistics version 9.3. SAS Inst Inc Cary NC. Selwet M. and M. Galbas. 2012a. Monitoring of selected genes in Campylobacter jejuni and Campylobacter coli isolates from domestic animals. Bull. Vet. Inst. Pulawy. 56: 283-286.

Selwet M. and M. Galbas. 2012b. Impact of the probiotic on the presence of selected virulence genes and drug - resistance among Campylobacter coli isolated from piglets. Bull. Vet. Inst. Pulawy. 56: 507-511.

Selwet M., T. Cłapa, M. Galbas, R. Słomski and F. Porzucek. 2015. The prevalence of Campylobacter spp. and occurence of virulence genes isolated from dogs. Pol. J. Microbiol. 64: 73-76.

Tambur Z.Ž., I.M. Stojanov, S.M. Konstantinonic, D.V. Jovanowic, D. Cenic-Miloševic and D.N. Opačic. 2010. Multi drug resistance of Campylobacter jejuni and Campylobacter coli to tested antibiotics in strains originating from humans, polutry and swine. Matica Srpska Proceed. Natural. Sci. 118: 27-37.

Tsai H.J., H.C. Huang, C.M. Lin, Y.Y. Lien and C.H. Chou. 2007. Salmonellae and Campylobacters in Household and Stray Dogs in Northern Taiwan. Vet. Res. Commun. 31: 931-939.

Zheng J., J. Meng, S. Zhao, R. Singh and W. Song. 2008. Campylobacter - induced interleukin-8 secretion in polarized human intestinal epithelial cells requires Campylobacter - secreted cytolethal distending toxin- and Toll-like receptor-mediated activation of NF-kappaB. Infect. Immun. 76: 4498-4508. 